\title{
Role of p52 (NF-кB2) in LPS Tolerance in a Human B Cell Line
}

\author{
Angela Wedel ${ }^{1}$, Marion Frankenberger ${ }^{1}$, \\ Gabi Sulski ${ }^{1}$, Irmhild Petersmann ${ }^{1}$, \\ Dmitry Kuprash ${ }^{2}$, Sergei Nedospasov ${ }^{3}$ and \\ H.W. Loems Ziegler-Heitbrock ${ }^{1, *}$ \\ ${ }^{1}$ Institute for Immunology, University of Munich, \\ D-80336 Munich, Germany \\ ${ }^{2}$ Intramural Research Support P rogram, SAIC Frederick, \\ NCI-FCRDC, Frederick, MD 21702, USA \\ ${ }^{3}$ Engelhardt Institute of Molecular B iology, \\ Russian Academy of Sciences, Moscow 117984, Russia \\ *Corresponding author
}

Cells of the weakly CD14 positive human B cell line RPMI 8226, clone 1, will mobilize NF- $\kappa B$ (p50/p65 and p50/p50) proteins and produce TNF mRNA when stimulated with lipopolysaccharide (LPS). When such cells are precultured with a low amount of LPS $(50-250 \mathrm{ng} /$ $\mathrm{ml}$ ) for 3 - 4 days followed by a secondary stimulation with a high dose of LPS $(1 \mu \mathrm{g} / \mathrm{ml})$ then the cytokine expression is strongly reduced, i. e. the cells have become tolerant.

Western blot analysis of proteins of the NF- $\mathrm{KB} / \mathrm{rel}$ family demonstrates cytoplasmic p50 and p65 for naive $B$ cells plus a low level of $p 52$. While with tolerance induction the pattern of $\mathrm{p} 50$ and $\mathrm{p} 65$ proteins remains essentially unchanged, the LPS tolerant 8226 cells show a dramatic increase of both $\mathrm{p} 52$ protein and its p100 precursor in the cytosol. This p52 is found strongly upregulated in Western blots of extracts from purified nuclei of tolerant cells. Also, gelshift analysis with the $-605 \kappa \mathrm{k}$ motif of the human TNF $5^{\prime}$-region shows an additional high mobility complex in LPS tolerant cells - a complex that is supershifted with an anti-p52 antibody.

Functional analysis with the -1064 TNF 5 '-region in front of the luciferase reporter gene demonstrates that transactivation of the TNF promoter is strongly reduced in tolerant cells. Also, overexpression of p52 will suppress activity of TNF promoter reporter gene constructs.

Taken together these data show that tolerance to LPS in the human R PMI 8226 B cell line involves upregulation of the p52 (NF-кB2) gene, which appears to be instrumental in the blockade of TNF gene expression. Key words: Endotoxin / Lipopolysaccharide / NF-kappaB / Tolerance.

\section{Introduction}

Lipopolysaccharide (LPS) derived from Gram-negative bacteria is a potent stimulator of monocytes/macrophages, leading to rapid production of cytokines like Tumor Necrosis Factor (TNF). LPS acts through binding to the CD14 receptor (Wright et al., 1990), a process facilitated by LPS binding protein (Tobias et al., 1986). CD14 is also expressed at a low level by granulocytes and by $B$ cells, both of which can be activated through this receptor (Ziegler-Heitbrock and Ulevitch, 1993). In addition some other cells that do not express CD14 may be activated by LPS and this process involves soluble CD14 (Frey et al., 1992; Pugin et al., 1993). The LPS-sCD14 complex may act through binding to toll-like receptors TLR 2 and TLR4, which in addition can mediate LPS activation in the $a b-$ sence of CD14 (Kirschning et al., 1998; Poltorak et al., 1998; Yang et al., 1998). Hence, LPS can lead to activation of many cell types, all of which may respond with production of proinflammatory cytokines.

When stimulated with LPS repeatedly, monocytes/ macrophages lose their ability to respond (Haas et al., 1989; Virca et al., 1989; reviewed by Ziegler-Heitbrock, 1995), a process termed desensitization or tolerance. In monocytes tolerance appears to be mediated by an upregulation of the $p 50(N F-\kappa B 1)$ gene product, which in the nucleus blocks transactivation of cytokine genes. Recent evidence indicates that this mechanism of transcriptional blockade may have more general importance in that it also occurs in murine macrophages and even in murine T cells (Sundstedt et al., 1996; Ziegler-Heitbrock et al., 1997).

We now show that a similar but not identical mechanism appears to operate in a human B cell line. We report that LPS can induce tolerance in the weakly CD14 positive RPMI 8226 clone $1 \mathrm{~B}$ cell line and we show that no upregulation of $\mathrm{p} 50$ occurs, but that this process involves a dramatic increase in the expression of the p52 (NF- кB2) gene, which may be instrumental in blocking gene expression upon secondary LPS stimulation.

Thus it appears that LPS tolerance in different cell types operates via a similar mechanism, i. e. through upregulation of a non-transactivating transcription factor. The different cell types do, however, exploit different molecules to achieve this aim, in that $\mathrm{p} 50$ is used by monocytes while, as shown here, $B$ cells may employ $p 52$ of NF- $\mathrm{kB}$.

\section{Results}

RPMI 8226 B cells do not express detectable TNF mRNA without stimulation, but LPS at $1 \mu \mathrm{g} / \mathrm{ml}$ will induce expres- 
sion of this gene as evidenced by RT-PCR (Figure 1, lanes 1 and 2). When the cells are precultured with a low dose of LPS $(50 \mathrm{ng} / \mathrm{ml})$ for 3 days followed by stimulation with the high dose of $1 \mu \mathrm{g} / \mathrm{ml}$ then no TNF mRNA can be induced (Figure 1, lane 4). These data indicate that the RPMI 8226 cells have become tolerant to LPS stimulation. In classical systems of tolerance the receptor molecule is down-regulated, and we asked whether the same applies to the $B$ cell line. The relevant receptor for LPS is the CD14 molecule, and this molecule was shown to mediate LPS-induced cytokine production in these cells (Ziegler-Heitbrock et al., 1994a). Flow cytometry analysis did not, however, reveal any decrease of CD14 expression with tolerance induction by LPS (data not shown).

We therefore turned to the analysis of molecules involved in signal transduction. One prominent transcription factor involved in LPS signalling is NF- $\mathrm{kB}$.

Gel shift analysis with the $-605 \kappa B$ motif from the human TNF promoter revealed a low level of constitutive binding, but with LPS stimulation the nuclear extracts contained

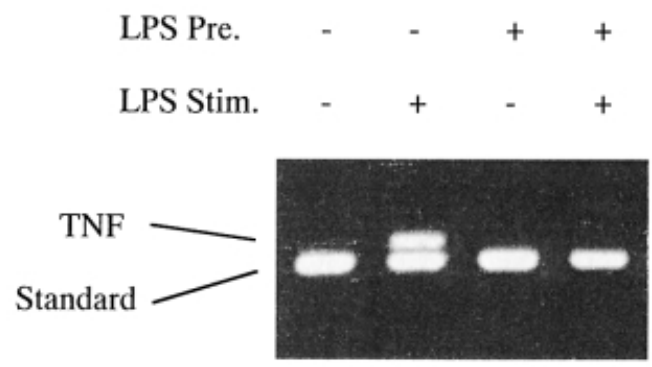

Fig. 1 TNF mRNA Expression in RPMI 8226 Cells Induced by LPS.

RPMI 8226 cells were precultured with or without LPS $(50 \mathrm{ng} / \mathrm{ml})$ followed by stimulation with LPS at $1 \mu \mathrm{g} / \mathrm{ml}$ for $4-6 \mathrm{~h}$. Cell lysates were spiked with CRNA standard, reverse transcribed and subjected to PCR. Products were separated on agarose gels and visualized with ethidium bromide (1 of 7 similar experiments).

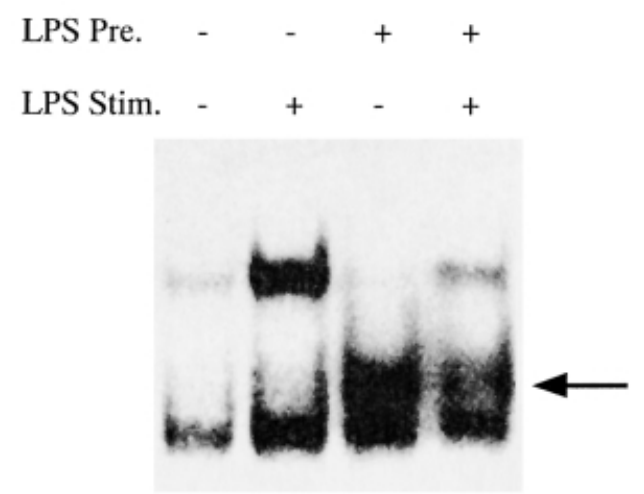

Fig. 2 LPS-Induced Mobilization of NF- $\kappa B$ Proteins in RPMI 8226 Cells.

Cells were precultured with or without LPS $(50 \mathrm{ng} / \mathrm{ml})$ followed by stimulation with or without LPS at $1 \mu \mathrm{g} / \mathrm{ml}$. Nuclear extracts were admixed with the radio-labelled $-605 \mathrm{NF}-\kappa \mathrm{B}$ motif of the human TNF promoter and separated on a non-denaturing polyacrylamide gel. Dryed gels were exposed to X-ray films (1 of 7 experiments). abundant DNA binding proteins with a strong low mobility (upper) band and a high mobility (lower) band (Figure 2). Supershift analysis revealed that the upper complex consists of $p 50$ and $p 65$ while the lower complex contains p50 homodimers (data not shown).

LPS stimulation of tolerant cells revealed an entirely different picture: here some p50/p65 (upper complex) was still mobilized into the nucleus (Figure 2, lane 4) but an additional diffuse band appeared (see arrow in Figure 2) with somewhat lower mobility as compared to the p50 homodimer.

In supershift analysis of tolerant cells the nuclear extracts of control treated cells again showed this reduced mobilization of p50/p65 and a predominance of the new complex (Figure 3, lane 1). Treatment with anti-p50 antiserum removed only the high mobility complex and the faint low mobility complex (see top and bottom arrow in Figure 3), such that the new complex became clearly visible. This complex is supershifted exclusively with anti-p52 antiserum, leaving all the other complexes unaffected. These data indicate that in tolerant B cells $p 52$ is upregulated and mobilized into the nucleus where it binds to NF- $\kappa$ B motifs.

This contention is supported by Western blot analysis. Cytosolic extracts of naive RPMI 8226 cells contained a weak p52 band that is diminished upon LPS stimulation (Figure 4, lanes 1 and 2). In these naive cells no p100 precursor protein is detected. When the cells are precultured with LPS however, a strong band for this precursor protein appears in the cytoplasm and there is also a dramatic increase in the mature $\mathrm{p} 52$ protein in LPS-precultured cells with or without LPS stimulation (Figure 4, lanes 3 and 4).
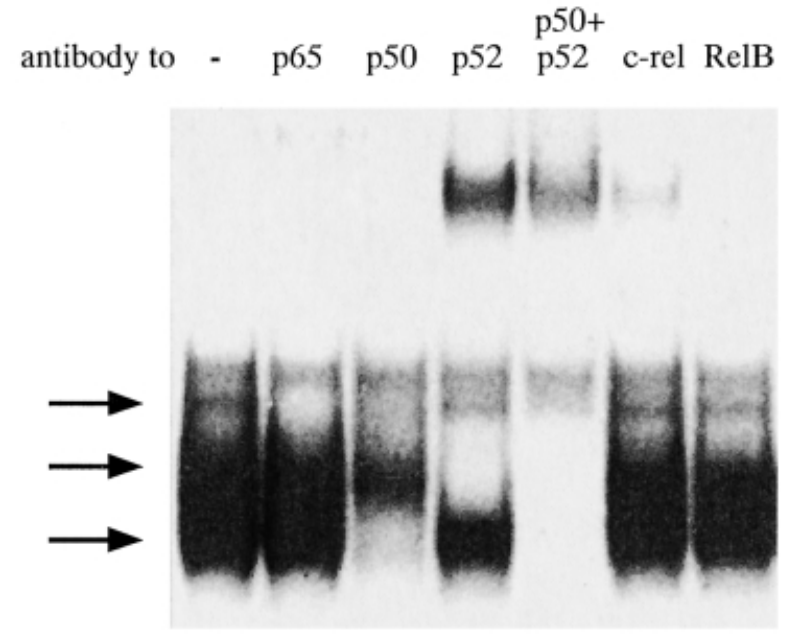

Fig. 3 Supershift Analysis of NF-кB Proteins from Nuclear Extracts of Naive and Tolerant RPMI 8226 Cells.

Nuclear extracts from cells with or without preculture with LPS at $50 \mathrm{ng} / \mathrm{ml}$ followed by stimulation with LPS at $1 \mu \mathrm{g} / \mathrm{ml}$ were admixed with polyclonal antibodies against different NF- $\mathrm{kB} / \mathrm{rel}$ proteins, followed by addition of radio-labelled $-605 \mathrm{NF}-\kappa \mathrm{B}$ motif of the human TNF promoter. After separation on a non-denaturing polyacrylamide gel the dried gel was exposed to an X-ray film (1 of 3 experiments). 
Analysis of nuclear extracts (Figure 4, lanes 5 - 8) shows no p100 band anywhere (which demonstrates that there is no cytoplasmic contamination of the sucrose-gradient purified nuclei). 552 protein is found in very low abundance in nuclei of naive cells and this increases somewhat with LPS stimulation (Figure 4, lanes 5 and 6). Upon LPS preculture nuclear p52 increases dramatically both with and without additional LPS stimulation (Figure 4, lanes 7 and 8). These data show that the unique feature in LPS tolerant RPMI 8226 B cells is the upregulation of p52 protein, which is mobilized into the nucleus.

\begin{tabular}{|c|c|c|c|c|c|c|c|}
\hline \multicolumn{5}{|c|}{ Cytosol } & \multicolumn{3}{|c|}{ Nucleus } \\
\hline LPS Pre. & - & - & + & + & - & - & \\
\hline LPS Stim. & - & + & - & + & - & + & . \\
\hline
\end{tabular}

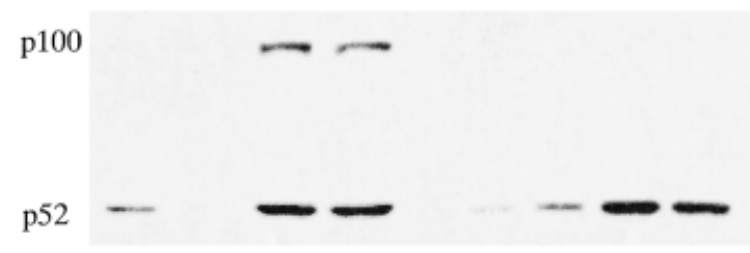

Fig. 4 Western Blot Analysis of Cytosolic and Nuclear NF- $\mathrm{kB2}$ Gene Products.

Cells were precultured for 3 days with or without LPS $(100 \mathrm{ng} / \mathrm{ml})$ followed by stimulation with or without LPS at $1 \mu \mathrm{g} / \mathrm{ml}$ for $1 \mathrm{~h}$. Cytosolic extracts were then prepared directly by ultrasound disruption For nuclear extracts viable cells were first purified by ficollhypaque density gradient separation, nuclei were obtained by douncing and these were separated over a $57 \%(\mathrm{w} / \mathrm{v})$ sucrose gradient, followed by extract preparation under low salt conditons. Thirty $\mu \mathrm{g}$ of cytosolic protein or $6 \mu \mathrm{g}$ of nuclear protein per lane were separated on a Tris-glycine gel and blots were reacted with an antibody against human $\mathrm{p} 52$ followed by goat anti-rabbit peroxidase and ECL reagent.

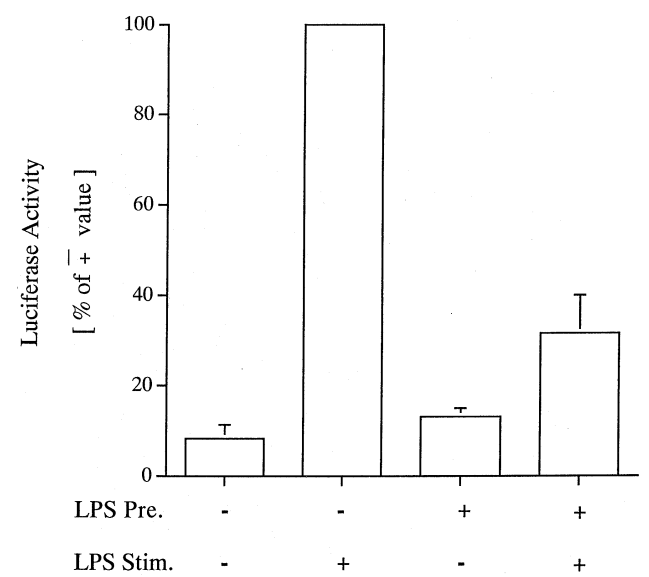

Fig.5 TNF Promoter Reporter Gene Analysis in Naive and Tolerant RPMI 8226 Cells.

Cells were transfected by DEAE-dextran with the pTNF-1064 luci- $\beta$ construct and were precultured with or without LPS (250 $\mathrm{ng} / \mathrm{ml})$ for 4 days. After stimulation with LPS $(1 \mu \mathrm{g} / \mathrm{ml}$ for $4 \mathrm{~h})$, cell lysates were obtained by 3 freeze-thaw cycles and luciferase enzyme activity was determined in a luminometer. Relative light units (RLUs) for LPS-stimulated naive cells were set at $100 \%$. RLUs for the $100 \%$ value were on the order of $25 \times 10^{4}$ per $100 \mu \mathrm{g}$ of protein. Average \pm SD of 5 experiments.
Next we analyzed the functional consequences of the increased expression of p52. For this we studied the activity of the $5^{\prime}$ region (-1064 bp) of the TNF gene in a luciferase reporter construct. DEAE-dextran transfected naive RPM 8226 cells gave an average 12 -fold increase in luciferase enzyme activity when stimulated with LPS. In tolerant cells transactivation was only 2.5 -fold (Figure 5 ). Similar data were obtained with reporter gene constructs containing a trimer of the $-605 \mathrm{NF}-\mathrm{kB}$ site of the TNF promoter (data not shown). This indicates that tolerance is operative at the transcriptional level.

Finally we asked whether overexpression of $\mathrm{p} 52$ directed by an expression plasmid is able to down-regulate transactivation from the human TNF promoter. HEK293 cells were cotransfected with a TNF promoter luciferase reporter plasmid plus different expression plasmids. As shown in Figure 6, cotransfection with p65 will strongly enhance TNF promoter activity by an average factor of 22 (compare columns 1 and 2, Figure 6). This enhanced reporter gene activity is counteracted by overexpression of p52, which reduces activity to $20 \%$ of the p 65 value (Figure 6 , column 3), while the empty expression plasmid even leads to a slight increase in luciferase activity.

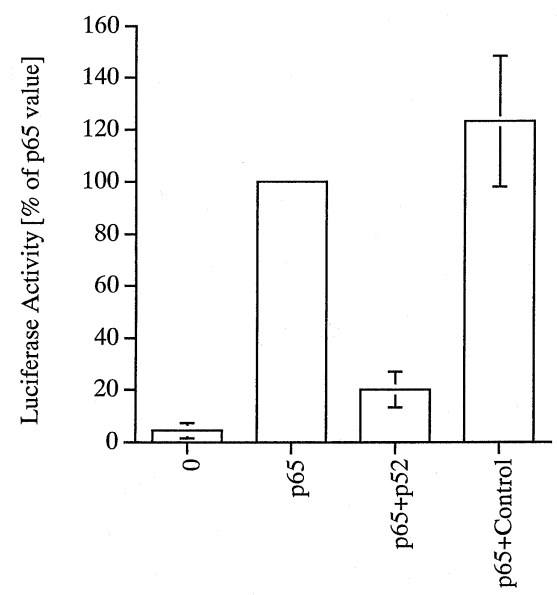

Fig. 6 Supression of TNF P romoter Activity by p52 (NF- $\mathrm{B}$ 2) The human TNF promoter luciferase reporter gene construct was cotransfected with expression plasmids encoding for $p 65$ or $p 52$ or with an empty expression plasmid (control) using the Ca-phosphate procedure. After overnight culture cell lysates were obtained by 3 freeze-thaw cycles and luciferase enzyme activity was determined in a luminometer. Relative light units for cells transfected p 65 were set at $100 \%$. RLUs for the $100 \%$ value were on the order of $8 \times 10^{6}$ per $\mu \mathrm{g}$ protein. Average \pm SD of 3 experiments.

\section{Discussion}

The phenomenon of tolerance to LPS was noted early on with respect to the febrile response of the rabbit (Beeson, 1947). It was suggested to be controlled at the cellular level (Greisman et al., 1966) and in fact later on LPS tolerance was adoptively transferred by mouse macrophages 
(Freudenberg and Galanos, 1988). LPS tolerance was then adapted to in vitro treatment of monocyte/macrophage cell lines like Mono Mac 6 orRAW 264.7 (Haas etal., 1989; Virca etal., 1989) and here it was shown that the TNF gene was down-regulated at the mRNA level. While downregulation of TNF is the salient feature of LPS tolerance other products of monocytes may even be upregulated (Zhang and M arrison, 1993; Knopf et al., 1994; West et al., 1997) and this includes anti-inflammatory molecules like IL-10 and IL- 1 receptor antagonist (Frankenberger et al., 1995; Randow et al., 1995).

Since the cell surface receptor for LPS, the CD14 molecule, appeared not to be down-regulated in LPS tolerance (Mathison et al., 1993; Ziegler-Heitbrock et al., 1994b) it was speculated that elements of signal transduction might be altered. We have hypothesized that p50/p50 homodimers may fulfill such a function in LPS tolerant monocytes (Ziegler-Heitb rock et al., 1994b, 1995). In the present report we asked whether a similar mechanism may operate in human B cells.

Human B cells may express a low level of CD14 on the cell surface (Labeta et al., 1991; Medeiros et al., 1991; Morabito et al., 1987; Ziegler-Heitbrock et al., 1988). We have isolated RPMI 8226 clones from the $B$ cell line that exibit stable expression of CD14. LPS stimulation of such cells will lead to expression of cytokines IL-6, IL-10 (Ziegler-Heitbrock et al., 1994a) and TNF (this study). TNF is, in fact, a cytokine that is readily expressed by $B$ cells (Goldfeld and Maniatis, 1989; Sung et al., 1988). When the RPMI 8226 cells are precultured with LPS followed by a secondary LPS stimulation, then TNF mRNA expression is strongly reduced (Figure 1 ), demonstrating that tolerance to LPS can be induced and can be analyzed by looking at TNF gene expression.

Based on earlier studies in monocytes we analyzed the NF- $\mathrm{kB}$ transcription factor complex in the RPMI $8226 \mathrm{~B}$ cell line.

The p52 protein appears to be of crucial importance in LPS tolerance in this cell line since Western blot analysis demonstrates a pronounced upregulation of $p 52$ and its p100 precursor. The upregulated p52 was also readily detected in gelshift analysis and could be identified by supershift with anti-p52 (Figure 3).

In monocytes this increased transcription factor complex represents $\mathrm{p} 50$ homodimers, which appear to be responsible for tolerance in that they occupy NF- $\mathrm{kB}$ sites without transactivation such that expression of genes like TNF is blocked (Ziegler-Heitbrock et al., 1994b, 1995). In fact, p50 knock-out mice were shown not to develop LPS tolerance and overexpression of $p 50$ in cotransfection experiments blocked TNF gene expression (Bohuslav et al., 1998; Kastenbauer and Ziegler-Heitbrock, 1999). For RPMI 8226 cells the present study clearly demonstrates that $\mathrm{p} 50$ is not involved but products of the NF- $\mathrm{kB} 2$ gene, i. e. p52 and its precursor, p100 are upregulated. Since p52 lacks a transactivation domain, its binding to DNA may lead to a blockade of transcription since transactivating complexes do not get access to the site.
Several reports have documented that overexpression of $p 50$ or p52 can lead to reduced gene expression (Schmitz and Bäuerle, 1991; Franzoso et al., 1992; Plaksin et al., 1993; Dobrzanski et al., 1995). Here we could demonstrate that overexpression of such p52 is capable of suppressing the human TNF promoter activity.

While this is the first study to describe a role for $p 52$ in LPS tolerance, there have been several studies by others that support our general concept (Ziegler-Heitbrock et al., 1994b) of transcriptional blockade by a non-transactivating NF-кB complex. Lægreid etal. noted that preculture of SW480 adenocarcinoma cells with agonistic TNF receptor antibodies led to a strong increase of $p 50$ homodimers in gelshift analysis (Lægreid et al., 1995). Also, Sunstedt et al. (1996) found in TCR transgenic mice that repeated injection of superantigen in vivo resulted in a predominance of p50/p50 homodimers in the tolerant $T$ cells.

Studies failed to detect an increase of p50/p50 in LPS tolerance that analyzed responses after very short periods (4 - 5 h) of tolerance induction (Takasuka et al., 1995; Kravchenko et al., 1996), which may be too short to allow for induction of expression of NF- $\kappa B 1$ and 2 genes.

Of note, the detection of p50/p50 homodimers in gelshift assays does require DNA binding motifs that read CCC at the 3 'end. Motifs that contain only CC are unable to bind p50/p50 with sufficient affinity (Kunsch et al., 1992; Frankenberger and Ziegler-Heitbrock, 1997) to allow for their detection in gelshift.

In LPS tolerance there are several possible levels of regulation that may account for the non-responsiveness. This includes the level of G-proteins, of kinases or other elements of signal transduction, the transcriptional level, the translational regulation via $\mathrm{AU}$-rich 3 '-elements of the mRNA, or post-translational effects (Zuckerman et al., 1989; C offee et al., 1992; Marchant et al., 1996). While all of these may contribute to the non-responsiveness to a varying degree, we do suggest that the blockade of gene expression via upregulation of a non-transactivating NF$\kappa \mathrm{B}$ complex will explain a large part of the observed effect and will provide a general mechanism that counteracts the action of classical NF- $\mathrm{kB}$ on a variety of genes.

Since tolerance to LPS may be induced by different types of stimuli (reviewed by Cavaillon, 1995) we may speculate that these stimuli also lead to an increased expression of the genes for either $p 50$ (NF- $\mathrm{kB} 1$ ) or, as suggested by the present report, also for p52 (NF-кB2). Furthermore, as discussed above, the concept of transcriptional blockade via NF-кB1 or 2 gene products may not only extend to other inducers of LPS tolerance but also to tolerance to stimulation via TNF receptors or T cell receptors.

\section{Material and Methods}

\section{Cell Culture}

In a previous study the original RPMI 8226 B cell line (Matsuoka et al., 1967) was found to inconsistently express cell surface CD14. 
We derived a subclone, termed clone 1 , which shows stable expression of CD14 (Ziegler-Heitbrock et al., 1994a) and this clone was used throughout this study. The cells were cultured in RPMI 1640 fortified with non-essential amino acids, L-glutamine, streptomycin and penicillin.

This medium was ultrafiltered through a Gambro 2000 column (Gambro, Hechingen, Germany) in order to remove contaminant LPS, followed by addition of $10 \%$ fetal calf serum. The cells were cultured in $75 \mathrm{~cm}^{2}$ flasks (Costar, Cambrige, MA, USA) or 6-well plates (Costar), with or without LPS from S. minnesota (Sigma, Deisenhofen, Germany), at $50-250 \mathrm{ng} / \mathrm{ml}$ for $3-4$ days. The slightly adherent cells were then recovered with a cell scraper washed twice, adjusted to $2-10 \times 10^{6}$ cells $/ \mathrm{ml}$ and were stimulated with LPS at $1 \mu \mathrm{g} / \mathrm{ml}$ for $1-6$ hours.

\section{Flow Cytometry}

For analysis of CD14 cell surface expression, cells with and without LPS preculture were reacted on ice with either FITC-conjugated My-4 or with the respective isotype control (Coulter, Krefeld, Germany) followed by analysis of 10000 cells per sample in an EPICS V flow cytometer (Coulter).

\section{Western Blotting}

Cytoplasmic or nuclear proteins ( $10-20 \mu \mathrm{g} / \mathrm{lane})$ were separated on $4-12 \%$ Tris/glycine gels (Novex through Anamed, Offenbach, Germany) and were transferred to Hybond ECL (enhanced chemoluminescence) nitrocellulose membranes (Amersham Braunschweig, Germany) by electroblotting. Membranes were reacted with 1:5000 dilutions of antibodies against p50, p52 and p65 that were kindly provided by Nancy Rice (Frederick, MD, USA). After reaction with $\mathrm{F}(\mathrm{ab})_{2}$ goat anti-rabbit Ig peroxidase conjugate (1:10000, Sigma), blots were incubated with $E C L$ reagent (Amersham) and exposed to Hyperfilm ECL (Amersham).

\section{TNF-PCR}

The determination of TNF mRNA expression was performed essentially as described (Frankenberger et al., 1995). In brief, cell lysates taken after $4 \mathrm{~h}$ of stimulation were admixed with CRNA standard. The total RNA was isolated and reverse-transcribed using oligo (dT) primers. The cDNA was then amplified with specific primers and after 45 cycles the product was separated on a $1.4 \%$ agarose gel in the presence of ethidium bromide.

\section{Gel Shift Analysis}

Nuclear extracts were isolated according to Dignam et al. (1983) and were admixed with a [ ${ }^{32} \mathrm{P}$-labeled double-stranded oligonucleotide representing the $-605 \mathrm{NF}-\mathrm{\kappa B}$ site of the human TNF promoter (Ziegler-Heitbrock et al., 1993). After 15 min of incubation at $21^{\circ} \mathrm{C}$ samples were electrophoresed on nondenaturing polyacrylamide gels in $0.25 \times$ TBE buffer $(22.5 \mathrm{~mm}$ Tris-borate, $0.5 \mathrm{~mm}$ EDTA, pH 8.5).

For supershift analysis $2 \mu$ of the respective antibody or preimmune serum were added subsequently to the $\left.{ }^{32} \mathrm{P}\right]$-labeled oligonucleotide, and the samples were incubated another $30 \mathrm{~min}$ on ice. Anti-p50 (serum 2), was kindly provided by A. Israël, Institut Pasteur, Paris, France, (Kieran et al., 1990). Anti-p52 was prepared against amino acids 2 - 18 of the human protein (Nancy Rice, personal communication), kindly provided by Nancy Rice, Frederick, MD, USA. The other antibodies (anti-p65 =sc-372X , $\mathrm{c}-\mathrm{rel}=\mathrm{sc}-70 \mathrm{X}$ and relB $=\mathrm{sc}-226 \mathrm{X}$ ) were purchased from Santa Cruz Biotechnology, Santa Cruz, CA, USA.

\section{Reporter Gene Analysis}

The pTNF-1064 luci- $\beta$ reporter plasmid containing the human TNF 5 '-region was obtained by exchanging the mouse $\beta$-globin promoter of the p $\beta$ TATA luci- $\beta$ reporter plasmid against the Hindlll/Bglll fragment from the TNF 5 '-region $\mathrm{pxP2}$ luciferase construct (Ziegler-Heitbrock et al., 1994b). The pßTATA.luci reporter plasmid contains $3^{\prime}$ to the luciferase gene the rabbit $\beta$ globin intron (Kastenbauer et al., 1996).

RPMI 8226 cells were transfected with the constructs $(2-5 \mu \mathrm{g}$ of DNA/ $10^{7}$ cells) according to Shakhov et al. (1990) using DEAEdextran $(62.5 \mu \mathrm{g} / \mathrm{ml})$. Cells were then cultured for 4 days with or without LPS $(250 \mathrm{ng} / \mathrm{ml})$, followed by LPS stimulation $(1 \mu \mathrm{g} / \mathrm{ml})$ for $4 \mathrm{~h}$. Luciferase activity in cell lysates was determined using a Model LB9501 luminometer (Berthold, Wildbad, Germany) and the Luciferase Assay System (E1500) from Promega (Madison, Wisconsin, USA).

For cotransfection analysis HEK 293 cells were seeded at $5 \times$ $10^{5}$ cells per well in 6 -well plates (Costar) and cultured overnight. Duplicates of 2 wells each were then transfected by the $\mathrm{Ca}$-phosphate method with luciferase reporter plasmid alone $(2 \mu \mathrm{g})$, with luciferase reporter plasmid plus $1 \mu \mathrm{g}$ of RCCMVp65 (Schmitz and Bäuerle, 1991, kindly provided by P.A. Bäuerle, Freiburg, Germany) or with luciferase reporter plasmid plus $1 \mu \mathrm{g}$ of RCCMVp65 plus either $1 \mu \mathrm{g}$ of RCCMVp52 expression plasmid (constructed by Alain Israël by cloning the HindIII-Pstl fragment that codes for amino acids 1 - 441 of p100 into the RcCMV plasmid, kindly provided by A. Israël, Institut Pasteur Paris, France) or $1 \mu \mathrm{g}$ of RcCMV empty expression plasmid. Cellular luciferase activity with measured after $24 \mathrm{~h}$.

\section{Acknowledgements}

We acknowledge the generous provision of antibodies by Nancy Rice and Alain Israël.

This work was supported by Deutsche Forschungsgemeinschaft grant ZI 288/1 to HWLZH and by SFB 217. Furthermore, the project has been funded in part with Federal funds from the National Cancer Institute, National Institutes of Health, under Contract No. N01-CO-56000. The contents of this publication do not necessarily reflect the view or policies of the Department of Health and Human Services, nor does mention of trade names, commercial products, or organizations imply endorsement by the U.S. Government.

\section{References}

Beeson, P.B. (1947). Tolerance to bacterial pyrogens. I. Factors influencing its development. J. Exp. Med. 86, 29 - 44.

Bohuslav, J ., Kravchenko, V.V., Parry, G.C., Erlich, J.H., Gerondakis, S., MackIman, N., and Ulevitch, R.C. (1998). Regulation of an essential innate immune response by the $\mathrm{p} 50$ subunit of F-kappaB. J . Clin. Invest. 102, 1645 - 1652.

Cavaillon, J.-M. (1995). The nonspecific nature of endotoxin tolerance. Trends Microbiol. 3, 320 - 324.

Coffee, K.A., Halushka, P.V., Ashton, S.H., Tempel, G.E., Wise, W.C., and Cook, J.A. (1992). Endotoxin tolerance is associated with altered GTP-binding protein function. J . Appl. Physiol. 73, $1008-1013$.

Dignam, J.D., Lebovitz, R.M., and Roeder, R.G. (1983). Accurate transcription initiation by RNA polymerase II in a soluble extract 
from isolated mammalian nuclei. Nucleic Acids Res. 11, 1475 1489.

Dobrzanski, P., Ryseck, R.-P., and Bravo, R. (1995). Specific inhibition of RelB/p52 transcriptional activity by the $\mathrm{C}$-terminal domain of p100. Oncogene 10, 1003 - 1007.

Frankenberger, M., Pechumer, H., and Ziegler-Heitbrock, H.W.L. (1995). Interleukin-10 is upregulated in LPS tolerance. J. Inflammation 45, 56 - 63.

Frankenberger, M., and Ziegler-Heitbrock, H.W.L. (1997). LPS Tolerance in monocyte / macrophages: Three 3' Cytosins are required in the DNA binding motif for detection of upregulated NF-kB p50 homodimers. Immunobiol. 198, 81 - 90.

Franzoso, G., Bours, V., Park, S., Tomita-Yamaguchi, M., Kelly, K., and Siebenlist, U. (1992). The candidate oncoprotein $\mathrm{Bcl}-3$ is an antagonist of p50/NF-kB-mediated inhibition. Nature 359, $339-342$.

Freudenberg, M.A., and Galanos, C. (1988). Induction of tolerance to lipopolysaccharide (LPS)-D-galactosamine lethality by pretreatment with LPS is mediated by macrophages. Infect. Immun. 56, 1352 - 1357.

Frey, E.A., Miller, D.S., J ahr, T.G., Sundan, A., Bazil, V., Espevik, T., Finlay, B.B., and Wright, S.D. (1992). Soluble CD14 participates in the response of cells to lipopolysaccharide. J. Exp. Med. $176,1665-1671$.

Goldfeld, A.E., and Maniatis, T. (1989). Coordinate viral induction of tumor necrosis factor alpha and interferon beta in human $B$ cells and monocytes. Proc. Natl. Acad. Sci. USA 86, 1490 1494.

Greisman, S.E., Young, E.J ., and Woodward, W.E. (1966). Mechanisms of endotoxin tolerance. IV. Specificity of the pyrogenic refractory state during continuous intravenous infusions of endotoxin. J . Exp. Med. 124, $983-1000$.

Haas, J .G., Thiel, C., Blömer, K., Weiss, E.H., Riethmüller, G., and Ziegler-Heitbrock, H.W.L. (1989). Downregulation of tumor necrosis factor expression in the human Mono Mac 6 cell line by lipopolysaccharide. J. Leukocyte B iol. 46, 11- 14.

Kastenbauer, S., Wedel, A., Frankenberger, M., Wirth, T., and Ziegler-Heitbrock, H.W.L. (1996). Analysis of promoter activity by polymerase chain reaction amplification of reporter gene mRNA. Anal. Biochem. 233, 137- 139.

Kastenbauer, S., and Ziegler-Heitbrock, H.W. (1999). NF-kappaB1 (p50) is upregulated in lipopolysaccharide tolerance and can block tumor necrosis factor gene expression. Infect. Immun. 67, $1553-1559$.

Kieran, M., Blank, V., Logeat, F., Vandekerckhove, J ., Lottspeich, F., Le Bail, O., Urban, M.B., Kourilsky, P., Baeuerle, P.A., and Israël, A. (1990). The DNA binding subunit of NF- $\mathrm{BB}$ is identical to factor KBF1 and homologous to the rel oncogene product. Cell 62, 1007-1018.

Kirschning, C.J ., Wesche, H., Merrill Ayres, T., and Rothe, M. (1998). Human toll-like receptor 2 confers responsiveness to bacterial lipopolysaccharide. J . Exp. Med. 188, 2091 - 2097.

Knopf, H.P., Otto, F., Engelhardt, R., Freudenberg, M.A., Galanos, C., Herrmann, F., and Schumann, R.R. (1994). Discordant adaptation of human peritoneal macrophages to stimulation by lipopolysaccharide and the synthetic lipid A analogue SDZ MRL953. J . Immunol. 153, 287 - 299.

Kravchenko, V.V., Steinemann, S., Kline, L., Feng, L., and Ulevitch, R.J. (1996). Endotoxin tolerance is induced in Chinese Hamster ovary cell lines expressing human CD14. Shock 5 , $194-201$.

Kunsch, C., Ruben, S.M., and Rosen, C.A. (1992). Selection of optimal $\kappa \mathrm{B} /$ Rel DNA-binding motifs: interaction of both subunits of NF- $\mathrm{KB}$ with DNA is required for transcriptional activation. Mol. Cell. Biol. 12, $4412-4421$.

Labeta, M.O., Landmann, R., Obrecht, J .P., and Obrist, R. (1991).
Human $B$ cells express membrane-bound and soluble forms of the CD14 myeloid antigen. Mol. Immunol. 28, 115 - 122.

Lægreid, A., Thommesen, L., Gullstein J ahr, T., Sundan, A., and Espevik, T. (1995). Tumor necrosis factor induces lipopolysaccharide tolerance in a human adenocarcinoma cell line mainly through the TNF p55 receptor. I. Biol. Chem. 270, 25418 25425.

Marchant, A., Gueydan, C., Houzet, L., Amraoui, Z., Sels, A., Huez, G., Goldman, M., and Kruys, V. (1996). Defective translation of tumor necrosis factor mRNA in lipopolysaccharidetolerant macrophages. J . Inflamm. 46, 114 - 123.

Mathison, J., Wolfson, E., Steinemann, S., Tobias, P., and Ulevitch, R. (1993). Lipopolysaccharide (LPS) recognition in macrophages. J . Clin. Invest. 92, 2053 - 2059.

Matsuoka, Y., Moore, G.E., Yagi, Y., and Pressman, D. (1967). Production of free light chains of immunoglobulin by a hematopoietic cell line derived from a patient with multiple myeloma. Proc. Soc. Exp. Biol. Med. 125, 1246 - 1250.

Medeiros, L.J ., Herrington, R.D., Gonzalez, C.L., J affe, E.S., and Cossman, J . (1991). My4 antibody staining of non-Hodgkin's lymphomas. Am. J. Clin. Pathol. 95, 363 - 368.

Morabito, F., Prasthofer, E.F., Dunlap, N.E., Grossi, C.E., and Tilden, A.B. (1987). Expression of myelomonocytic antigens on chronic lymphocytic leukemia B cells correlates with their ability to produce interleukin-1. Blood 70, 1750 - 1757.

Plaksin, D., Bäuerle, P.A., and Eisenbach, L. (1993). KBF1 (p50 $\mathrm{NF}-\mathrm{\kappa B}$ homodimer) acts as a repressor of $\mathrm{H}-2 \mathrm{~Kb}$ gene expression in metastatic tumor cells. J. Exp. Med. 127, 1651- 1662.

Poltorak, A., He, X., Smirnova, I., Liu, M.Y., Huffel, C.V., Du, X., Birdwell, D., Alejos, E., Silva, M., Galanos, C., Freudenberg, M., Ricciardi-Castagnoli, P., Layton, B., and Beutler, B. (1998). Defective LPS signaling in $\mathrm{C} 3 \mathrm{H} / \mathrm{HeJ}$ and $\mathrm{C} 57 \mathrm{BL} / 10 \mathrm{SCCr}$ mice: mutations in TIr4 gene. Science 282, 2085 - 2088.

Pugin, J ., Schürer-Maly, C.-C., Leturcq, D., M oriarty, A., Ulevitch, R.J ., and Tobias, P.S. (1993). Lipopolysaccharide activation of human endothelial and epithelial cells is mediated by lipopolysaccharide-binding protein and soluble CD14. Proc. Natl. Acad. Sci. USA 90, 2744 - 2748.

Randow, F., Syrbe, U., Meisel, C., Krausch, D., Zuckermann, H., Platzer, C., and Volk, H.-D. (1995). Mechanism of endotoxin desensitization: involvement of interleukin 10 and transforming growth factor $\beta$. J . Exp. Med. 181, 1887 - 1892.

Schmitz, M.L., and Bäuerle, P.A. (1991). The p65 subunit is responsible for the strong transcription activating potential of NF-kB. EMBO J . 10, 3805 - 3817.

Shakhov, A.N., Collart, M.A., Vassalli, P., Nedospasov, S.A., and J ongeneel, C.V. (1990). кB-type enhancers are involved in LPS-mediated transcriptional activation of the TNF- $\alpha$ gene in primary macrophages. J. Exp. Med. 171, 35 - 47.

Sundstedt, A., Sigvardsson, M., Leanderson, T., Hedlund, G., Kalland, T., and Dohlsten, M. (1996). In vivo anergized CD4 ${ }^{+}$ $T$ cells express perturbed AP- 1 and NF- $\mathrm{KB}$ transcription factors. Proc. Natl. Acad. Sci. USA 93, 979 - 984.

Sung, S.S., J ung, L.K., Walters, J .A., Cheng, W., Wang, C.Y., and Fu, S.M. (1988). Production of tumor necrosis factor/cachectin by human B cell lines and tonsillar B cells. J . Exp. Med. 168, $1539-1551$

Takasuka, N., Matsuura, K., Yamamoto, S., and Akagawa, K.S. (1995). Suppression of TNF- $\alpha$ mRNA expression in LPSprimed macrophages occurs at the level of nuclear factor- $\kappa B$ activation, but not at the level of protein kinase C or CD14 expression. J . Immun. 154, $4803-4812$.

Tobias, P.S., Soldau, K., and Ulevitch, R.J . (1986). Isolation of a lipopolysaccharide-binding acute phase reactant from rabbit serum. J . Exp. Med. 164, 777-793.

Virca, G.D., Kim, S.Y., Glaser, K.B., and Ulevitch, R.J . (1989). 
Lipopolysaccharide induces hyporesponsiveness to its own action in RAW 264.7 cells. J . Biol. Chem. 264, 21951 - 21956.

West, M.A., Bennet, T., Seatter, S.C., Clair, L., and Bellingham, J . (1997). LPS pretreatment reprograms macrophage LPS-stimulated TNF and IL-1 release without protein tyrosine kinase activation. J. Leukoc. Biol. 61, 88 - 95.

Wright, S.D., Ramos, R.A., Robias, P.S., Ulevitch, R.J ., and Mathison, J.C. (1990). CD14, a receptor for complexes of lipopolysaccharide (LPS) and LPS binding protein. Science 249, $1431-1433$

Yang, R.-B., Mark, M.R., Gray, A., Huang, A., Xie, M.H., Zhang, M., Goddard, A., Wood, W.I., Gurney, A.L., and Godowski, P.J . (1998). Toll-like receptor-2 mediates lipopolysaccharide-induced cellular signaling. Nature 395, $284-288$.

Zhang, X., and Marrison, D.C. (1993). Lipopolysaccharide-induced selective priming effects on tumor necrosis factor alpha and nitric oxide production in mouse peritoneal macrophages. J. Exp. Med. 177, $511-516$.

Ziegler-Heitbrock, H.W.L. (1995). Molecular mechanism in tolerance to lipopolysaccharide. J . Inflammation 45, 13 - 26.

Ziegler-Heitbrock, H.W.L., and Ulevitch, R.J . (1993). CD14: cell surface receptor and differentiation marker. Immunol. Today $14,121-125$.

Ziegler-Heitbrock, H.W.L., Passlick, B., and Flieger, D. (1988). The monoclonal antimonocyte antibody $M y 4$ stains $B$ lymphocytes and two distinct monocyte subsets in human peripheral blood. Hybridoma 7, 521 - 527.
Ziegler-Heitbrock, H.W.L., Sternsdorf, T., Liese, J ., Belohradsky, B., Weber, C., Wedel, A., Schreck, R., Bäuerle, P., and Ströbel, M. (1993). Pyrrolidine dithiocarbamate inhibits NF-кB mobilization and TNF production in human monocytes. J . Immunol. 151,6986 - 6993.

Ziegler-Heitbrock, H.W.L., Pechumer, H., Petersmann, I., Durieux, J .J ., Vita, N., Labeta, M.O., and Ströbel, M. (1994a). CD14 is expressed and functional in human B cells. Eur. J. Immunol. 24, 1937 - 1940.

Ziegler-Heitbrock, H.W.L., Wedel, A., Schraut, W., Ströbel, M. Wendelgass, P., Sternsdorf, T., Bäuerle, P., Haas, J .G., and Riethmüller, G. (1994b). Tolerance to lipopolysaccharide involves mobilization of nuclear factor $\kappa B$ with predominance of p50 homodimers. J. Biol. Chem. 269, 17001 - 17004.

Ziegler-Heitbrock, H.W.L., Frankenberger, M., and Wedel, A. (1995). Tolerance to lipopolysaccharide in human blood monocytes. Immunobiol. 193, 217 - 223.

Ziegler-Heitbrock, H.W.L., Petersmann, I., and Frankenberger, M (1997). p50 (NF-KB1) is upregulated in LPS tolerant P388D1 murine macrophages. Immunobiol. 198, 73 - 80.

Zuckerman, S.H., Evans, G.F., Snyder, Y.M., and Roeder, W.D. (1989). Endotoxin-macrophage interaction: post-translational regulation of tumor necrosis factor expression. J. Immunol. $143,1223-1227$.

Received April 27, 1999; accepted J uly 30, 1999 